\title{
Comments
}

\section{A Student of Year 12 in Harrow International School Hong}

\author{
Kong \\ Nanqi Zhou ${ }^{1 *}$ \\ ${ }^{1}$ Tuen Mun, New Territories, Hong Kong \\ * Nanqi Zhou, Tuen Mun, New Territories, Hong Kong \\ Received: July 21, 2018 \\ Accepted: August 9, 2018 \\ Online Published: August 18, 2018 \\ doi:10.22158/jepf.v4n3p260 \\ URL: http://dx.doi.org/10.22158/jepf.v4n3p260
}

\section{What Role Does Asymmetric Information Play in Financial Markets?}

George Akerlof introduced the idea that due to asymmetric information between the buyer and the seller in the lemons market, the market for second-hand vehicles will eventually go on the wane. Parallel to this argument, this essay discusses the extent of problem caused by information asymmetry in the financial market, with the most prominent issues being adverse selection, moral hazard and principal agent problem. Yet, with more regulation from the government and the market, some of these problems can be ameliorated, thus reducing the role that asymmetric information plays in the financial market.

Adverse selection is opportunism characterised by the informed party taking advantage of the uninformed party through an unobserved characteristic. In a financial contract, the borrower might take the advantage of asymmetric information to deceive the lender in order to seek a lower interest rate. Assume that there are equal proportions of two types of projects, $\mathrm{A}$ and $\mathrm{B}$, in the market seeking for loans from banks. Project A has a risk of failure of $10 \%$, while project B has a risk of failure of $50 \%$. The interest rate for B would certainly be higher than for A as there is a higher cost of capital. In this situation, the borrower who undertakes the riskier project might attempt to disguise the true nature of the project to the lender, for instance by reporting a $10 \%$ probability of failure instead of $50 \%$, which helps to reduce the cost of borrowing. Since the lender lacks information, he will establish an interest rate that is the mean between that charged for projects A and B. As a result A will suffer from an increased borrowing cost, whilst $B$ enjoys a lower borrowing cost. The interest rate may be higher than project A's rate of return, meaning that no borrowing will occur, while investors in project B will happily borrow. This means that mutually beneficial transactions will not occur and there will be a missing market for loans to less risky projects. 
However, there are measures to reduce the extent of this problem in real life. In Akerlof's Quality uncertainty and the Market Mechanism, he has mentioned the use of screening and signalling to resolve the problems of adverse selection. Screening is an action by the uniformed party to gain information. In the borrow-lender relationship, since the lender is the uninformed party, he can ask for assistance from a rating agency, such as Moody's Investors Services, that can grade the risk of the project. On the other hand, signalling is conducted by the informed side. The borrower for project A might want to "signal" to the lender about its low-risk to acquire a lower interest rate. However, the effectiveness of this measure relies on the credibility of the borrower, which can be reflected by credit worthiness and reputation. These measures thus ameliorate the problem for adverse selection in the financial market, such that the role played by asymmetric information is insignificant.

Another common predicament caused by asymmetric information in the financial market is moral hazard, which is opportunism characterised by the informed party taking advantage of the uninformed party through an unobserved action. A party would take more risk since he does not have to bear the full consequences of his actions. In 2007 the housing market was in full swing in the US, and together with low interest rates, demand for housing units was bullish. There were two types of customers in the banking system-subprime and prime customers. Subprime customers are more likely to default according to their credit record and financial abilities, yet the commercial banks were still willing to take the risk and allow the subprime customers to take out mortgage. This was because large banks in the economy were so vital that they were considered "too big to fail". The banks know that in the event of a crisis, the government will bail them out using taxpayers' money to avoid high unemployment and severe financial impacts on the economy. This gives them the incentive to take excessive risks, which is could have severe and even disastrous impacts on the financial market.

However, even though the FED had stepped in on numerous occasions to rescue some of the most important financial institutions such as Bear Sterns and AIG, it allowed Lehman Brothers Holdings, one of the biggest investment banks in the world, to proclaim itself insolvent on September 15th 2008en. As Lehman Brothers collapsed with $\$ 613$ billion in debt, shockwaves was sent across country, resulting in a loss of jobs of over 20 thousand employees and sparking international contagion. Across the globe, this triggered violent turmoil in the global financial market, and was a wakeup call to other institutions, reminding them that the government does not have the obligation to ensure that all large institutions are kept standing. The Global Financial Crisis, exacerbated by moral hazard, has however shaped the economy after the crisis. The FED demanded collateral for their loans and charged financial institutions with a high interest rate. Commercial banks were mandated to be kept separate from the investment banks, and banks were also subject to more stringent stress tests to ensure flexibility and responsiveness in the event of another financial crisis. In this respect, although asymmetric information had adversely impacted the global economy, the changes in legislation brought about by the crisis made financial markets less susceptible to future problems. 
Apart from moral hazard, the principal-agent problem is considered another problem caused by asymmetric information in the financial market. Agency problem, a special case of moral hazard, is caused by the segregation of corporation ownership from management rights under the modern enterprise mechanism. Financial innovation in the 2008 financial crisis demonstrates a classic example of PA problem, where financial managers put risky and less risky projects together, cut them up and sold them off to customers who did not know that there were risky projects in the portfolio. Since principal (customers) and the agent (manager)'s interest are not aligned, the agent might exploit his superior information to maximise his own gain, instead of acting for the principal's best interest. As a result, agency costs are incurred since supervision is necessary and optimal contracts need to be drawn up. Optimal contracts require large amounts of time and resources, and often need to be erecallibrated as time passes as changes in the external environment impacts the effectiveness and feasibility of the contracts. The key to mitigating this problem is to align the agents' interest with the principal's, not only by regulating the agents' conducts, but also by aligning the agents' interests with that of the owners'. As Jensen and Meckling argued in their 1976 paper on CEO incentives, a solution to the agency problem was to align shareholder and manager interests through stock options grants. The Employee Stock Options (ESO) offer option holders the right to buy a certain amount of company's stock at a predetermined price in a future time. However, this action is only permitted when the stock prices has rise above a certain level. This thus forms a common benefit community between the principal and the agent, incentivising the manager to grow the stock price. Assuming that stock value is determined by the Dividend Discount Model (DDM) and ROE remains constant, an increase in the growth rate of the company will result in an increase in stock value, which satisfies the "principal" as a share holder.

However, managers may not seek to increase growth of the company, but instead aim to manipulate stock prices to benefit more from their stock options, or engage in investments that are personally beneficial (Jensen \& Murphy, 1990). For example, the agent might intentionally hold down the stock price by spreading bad news before the release of the stock options plan. The good news will only be announced after the implementation of the incentive plan, hence pushing the price of the stocks up. According to the theory of management entrenchment (Jensen, 1983), if the managers occupy a large shareholding ratio, they might hold sway over the directorate, hence invading other investors' assets. Further empirical study shows that under the situation when the manager holds a relatively lower level of shares, the market constraint would push the manager to work harder hence maximise the value of the firm. The current financial market still lack an effective regulatory environment, thus the principal agent problem is still a prominent problem in financial markets.

In a nutshell, the existence of asymmetric information in the financial market has greatly influenced the actions of economic participants in the real world. Asymmetric information resulted in catastrophic results such as the $2008 \mathrm{GFC}$, but also brought about much needed revolution in the regulation of financial markets. The impact of the agency problem is less adverse, and, the presence of agency theory 
(Eisenhardt, 1989) can ameliorate these effects. As the laws and legislations surrounding financial markets become more comprehensive and mature, asymmetric information will play an increasingly smaller role.

\section{References}

Akerlof, G. A. (2003). The market for "lemons": Quality uncertainty and the market mechanism.

Busato, F., \& Coletta, C. M. (n.d.). A moral hazard perspective on financial crisis. Retrieved from https://www.businessperspectives.org/images/pdf/free/9309/BBS_2017_03cont_Busato.pdf

How did moral hazard contribute financial crisis 2008. (n.d.). Retrieved from https://www.investopedia.com/ask/answers/050515/how-did-moral-hazard-contribute-financial-cri sis-2008.asp

Iw Bebczuk, R. N. (n.d.). Asymmetric information in financial markets: Introduction and applications. Jensen, C. M., \& Murphy, K. J. (n.d.). CEO Incentives: It's Not How Much You Pay, But How.

Rosenblum, H., DiMartino, D., Renier, J. J., \& Alm, R. (n.d.). Fed Intervention: Managing Moral Hazard in Financial Crises. Retrieved from https://www.dallasfed.org/ /media/documents/research/eclett/2008/el0810.pdf 